\title{
RATE OF SHORT-TERM ABLATION OF EXPOSED GROUND ICE, BANKS ISLAND, NORTHWEST TERRITORIES, CANADA
}

\author{
By ANToni G. Lewkowicz \\ (Department of Geography, Erindale College, University of Toronto, Mississauga, \\ Ontario L5L 1C6, Canada)
}

\begin{abstract}
Energy fluxes and resultant short-term ablation rates were measured at a ground-ice slump on south-west Banks Island. Net radiation, as a proportion of the ablation flux, is greatest on days with high incident solar radiation, whereas on overcast days, sensible- and latent-heat inputs may supply more than half the necessary energy. A multiple regression equation using net radiation and a turbulent-energy term as independent variables explains $79 \%$ of the variation in the measured ablation fluxes. Overall, at least $60 \%$ of the energy used for ablation at the slump is derived from net radiation.
\end{abstract}

RÉsumÉ. Vitesse d'ablation sur de courtes périodes de temps pour de la glace reposant sur le sol, Banks Island, Territoires du Nord Ouest. Canada. Les flux d'énergie et les taux d'ablation qui en résultent ont été mesurés sur les falaises de glace de sol dans le sud ouest de Banks Island. La radiation nette, comme élément du flux d'ablation, est la plus forte les jours de forte radiation solaire incidente, tandis que les jours de ciel couvert, ce sont les chaleurs sensibles et latentes qui fournissent plus de la moitié de

\section{INTRODUCTION}

Ground-ice slumps (Mackay, 1966; French and Egginton, 1973), also termed retrogressive thaw-flow slides (Hughes, 1972; Heginbottom, 1978) and bimodal flows (McRoberts and Morgenstern, 1974), are common thermokarst features in areas of ice-rich permafrost. They usually form when a body of ground ice beneath a slope is exposed by coastal, lacustrine or fluvial erosion, or by mass movements. Heat exchange with the atmosphere during the summer months results in ablation of the exposed ice and retreat of the face. Ground-ice slumps can also be initiated by Man's activities, for example, in deep highway cuts in ice-rich permafrost (e.g. Smith and Berg, 1973; Pufahl and others, 1974; Brown and Kreig, 1983; Shu and Huang, 1983) and an understanding of the energy balance of the ablating ice face will assist in control of the form under these circumstances. Conceptually, ground-ice slumps are interesting geomorphic features since they provide the opportunity to observe the rapid evolution of form in response to contemporary processes.

The geomorphological processes operating in a groundice slump include (1) ablation of the ice-rich face, (2) collapse of the unfrozen and ice-poor headwall on to the ice by free fall and semi-circular movements, (3) slide and flow of the collapsed material off the ice-rich face, and (4) flow down-slope in the slump floor of mud derived from the headwall and from sediment inclusions in the ice (Fig. 1). This paper concentrates on ablation of the ice which is the process that drives slump growth.

The objective of the paper is to derive an equation that employs meteorological data to predict short-term ablation of ground ice. To fulfil this aim, rates of ablation and components of the energy causing melt must be examined. There is a paucity of data in the literature on l'énergie nécessaire. Une équation de régression multiple comprenant la radiation nette et un terme d'énergie turbulente comme variables indépendantes explique $79 \%$ de la variance des flux mesurés d'ablation. Mais le plus important est que au moins $60 \%$ de l'énergie utilisée pour l'ablation provient de la radiation nette.

ZuSAMMENFASSUNG. Kurzzeitige Ablationsrate von exponiertem Grundeis auf Banks Island, N.W.T., Kanada. Energieflüsse und durch sie bewirkte Ablationsraten wurden an einem Grundeissturz auf dem südwestlichen Banks Island gemessen. Die Netto-Strahlung als ein Teil des Albationsflusses ist an Tagen mit hoher einfallender Sonnenstrahlung am grössten, während an bedeckten Tagen das Aufkommen an fühlbarer und latenter Wärme mehr als die Hälfte der notwendigen Energie liefern dürfte. Eine Gleichung mit Mehrfachregression, welche die NettoStrahlung und einen Ausdruck für die Turbulenz-Energie als unabhängige Variable heranzieht, erklärt $79 \%$ der Schwankung in den beobachteten Ablationsflüssen. Insgesamt stammen mindestens $60 \%$ der Energie, die für Ablation an dem Sturz verbraucht wird, aus der Netto-Strahlung.

ablation rates or energy exchanges over exposed ground ice, exceptions for the former being Burn (unpublished) and Kerfoot (unpublished), and for the latter Pufahl and Morgenstern (1980). Most studies have concentrated on the measurement of headwall retreat of sluinps, since accurate assessment of ablation has been difficult without specialized instrumentation. No study is known to the writer in which direct measurements have been made simultaneously of short-term ( $<1$ d) ground-ice ablation rates and of a part of the energy exchange causing the ablation. This paper

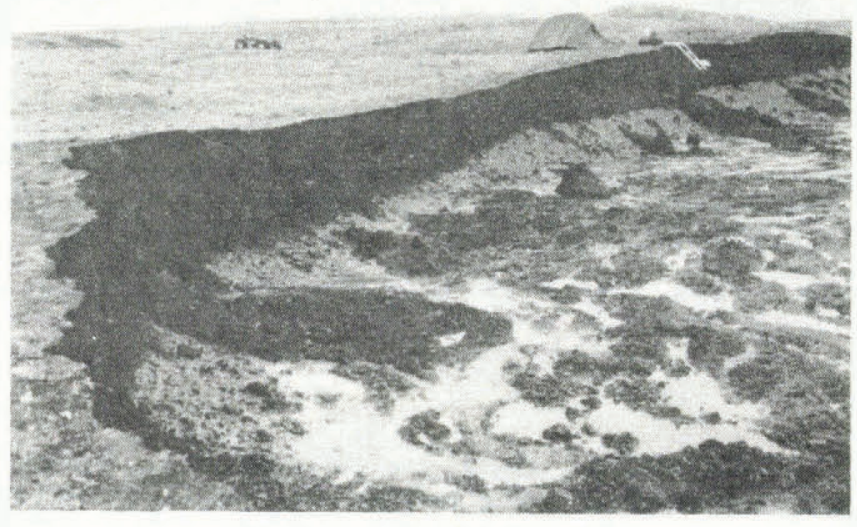

Fig. 1. Headwall of an active ground-ice slump (slump 1), Sand Hills moraine, 11 August 1983. Ablation of the ice-rich layer (light grey tone) results in undermining of the headwall and eventual collapse (bottom left and top right). Collapsed material and sediment inclusions from the ice mix with water derived from ablation and flow down-slope as lobes of mud in the slump floor. 


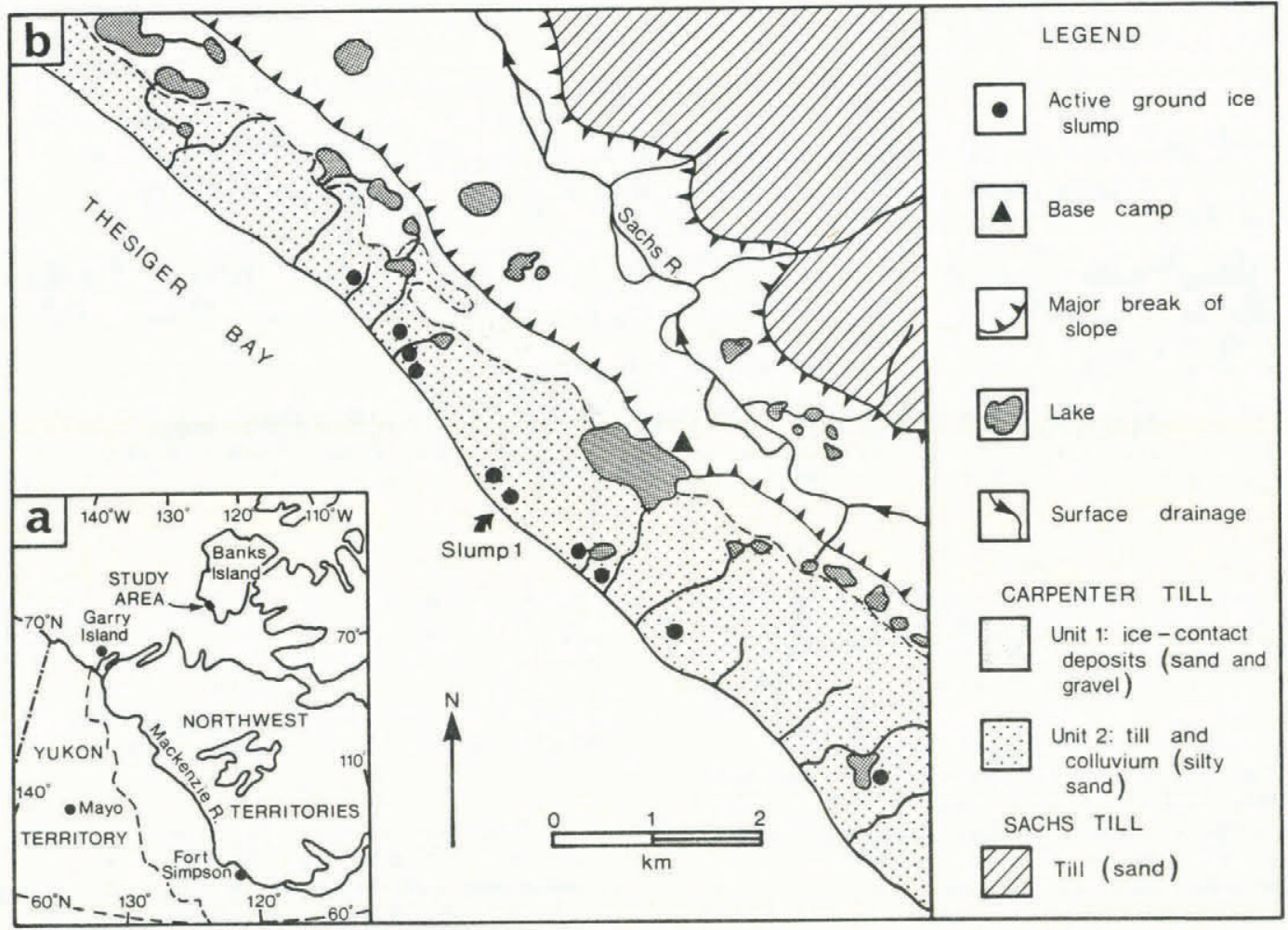

Fig. 2. (a) Location of the study area in south-west Banks Island, and of the comparative studies referred to in the text. (b) Position of active ground-ice slumps and study site in the Sand Hills moraine composed of Carpenter Till. (Source: field observations and air photograph A16286-87.)

describes such measurements and the derivation of predictive equations for ice ablation.

\section{STUDY AREA}

The study area is located in the Sand Hills moraine (lat. $71^{\circ} 43^{\prime}$ N., long. $124^{\circ} 05^{\prime}$ W.), south-west Banks Island (Fig. 2). This is a fresh lateral moraine complex attributed to a re-advance of ice in Thesiger Bay following initial retreat of the Thesiger lobe, probably prior to the late

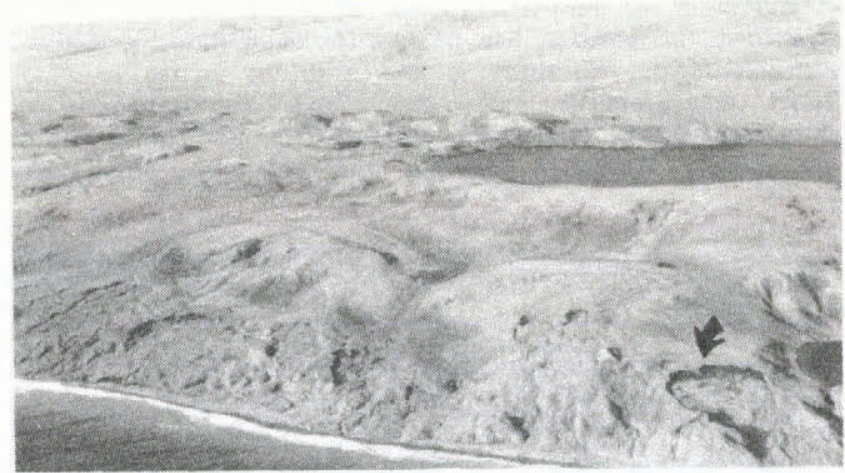

Fig. 3. Aerial view of the Sand Hills moraine towards the north. Note the numerous stabilized polycyclic slumps within $500 \mathrm{~m}$ of the coast and the active slump (arrowed bottom right).

Wisconsin (Vincent, 1983). The moraine, which Vincent (1982) described as being composed of bouldery Carpenter Till, can be divided into two morphological units. Unit 1 which parallels the Sachs River valley, is a series of ridges composed of ice-contact sands and gravels with a high boulder content. This unit has a number of large kettle lakes but no active or stabilized ground-ice slumps. Unit 2 , adjoining the coast, has been extensively affected by slumping (Fig. 3). It consists of till and colluvial deposits composed of silty sand with few boulders. Unit 2 is affected by coastal erosion and analyses of aerial photographs taken in 1952, 1958, and 1962 indicate that 2-3 m/a of coastal recession occurred during that period. These rates are similar to contemporary values recorded in the vicinity of Sachs Harbour, $50 \mathrm{~km}$ north-west of the study area (Harry and others, 1983). Coastal erosion has been responsible for the initiation of eight of the ten slumps that are currently active (see Fig. 2). The exceptions are one slump located inland on a lake shore and another started by fluvial erosion. Most of the more numerous stabilized slumps also seem to have been triggered by coastal processes, but a small number appear to have been caused by mass movements, possibly active-layer glides.

The extensive nature of present and past slumping activity indicates a widespread distribution of ground ice in unit 2 of the moraine. The generally high volumetric ice content (up to $100 \%$ in places in the active slumps), the areal extent of the ice and its topographic position, together indicate that the ice is derived from segregation processes or from the burial of glacier ice. Discrimination between these two origins, however, is difficult. Studies of unusual ice-cored features at the north-western end of Sand Hills suggest that the moraine complex might be at least partly cored by relict glacier ice (Harry, unpublished, p. 88-99). On the other hand, petrographic analyses of ice taken from one of the active slumps are inconclusive with some support being given to both hypotheses (Rothschild, unpublished, $p$. 60-63). Overall, therefore, the genesis of the ground ice remains an open question.

Climatic data from Sachs Harbour are probably quite representative of the study area. Mean air temperatures for the months of June, July, and August, when most ablation occurs, are $2.1^{\circ}, 5.9^{\circ}$, and $3.8^{\circ} \mathrm{C}$, respectively (Ministry of Transport records for the period 1955-78). Average incoming global radiation values on horizontal surfaces for the same months are 251, 228, and $133 \mathrm{~W} / \mathrm{m}^{2}$ (Phillips and Aston, 1980). However, the exposed ice in the Sand Hills moraine receives higher global radiation fluxes than these values, since most faces slope at angles of $25-50^{\circ}$ with directions between $160^{\circ}$ and $280^{\circ}$.

One of the active slumps (slump 1) in the Sand Hills moraine was selected for intensive investigation, since it appeared reasonably typical in terms of size, aspect, and 
ground-ice exposure. Most slumps in the area are of the polycyclic type (Mackay, 1966) and slump 1 was at least third-generation form, with its headwall composed of mudflow material from an old slump floor. Data were recorded in the field between 30 May and 23 July 1984. The meteorological record is virtually continuous over this period but the ablation record is concentrated between 25 June and 23 July.

\section{THEORY AND METHODS}

The ablation of an exposed ice face in a slump can be considered as a function of the energy balance (Lewkowicz, 1985):

$$
Q_{\mathrm{m}}=Q^{*}+Q_{\mathrm{h}}+Q_{\mathrm{e}}+Q_{\mathrm{g}}+Q_{\mathrm{p}}+Q_{\mathrm{d}}+Q_{\mathrm{w}}
$$

where $Q_{\mathrm{m}}$ is the energy flux available for ablation $\left(\mathrm{W} / \mathrm{m}^{2}\right)$, $Q^{*}$ is the net radiation flux $\left(\mathrm{W} / \mathrm{m}^{2}\right), Q_{\mathrm{h}}$ is the sensible-heat flux $\left(\mathrm{W} / \mathrm{m}^{2}\right), Q_{\mathrm{e}}$ is the latent-heat flux $\left(\mathrm{W} / \mathrm{m}^{2}\right), Q_{\mathrm{g}}$ is the ground-heat flux $\left(\mathrm{W} / \mathrm{m}^{2}\right), Q_{\mathrm{p}}$ is the heat flux from precipitation $\left(\mathrm{W} / \mathrm{m}^{2}\right), Q_{\mathrm{d}}$ is the heat flux from debris falling on to the ice $\left(\mathrm{W} / \mathrm{m}^{2}\right)$, and $Q_{\mathrm{w}}$ is the heat flux from water flowing down the ice $\left(\mathrm{W} / \mathrm{m}^{2}\right)$.

$Q^{*}$ in Equation (1) can be broken down into shortand long-wave components, while $Q_{\mathrm{h}}$ and $Q_{\mathrm{e}}$ can be subdivided further using the bulk-transfer approach (e.g. Male and Gray, 1981):

$$
\begin{aligned}
Q_{\mathrm{m}} & =K \downarrow(1-\alpha)+L^{*}+D_{\mathrm{h}} \cdot U_{\mathrm{z}}\left(T_{\mathrm{a}}-T_{\mathrm{s}}\right)+ \\
& +D_{\mathrm{e}} \cdot U_{\mathrm{z}}\left(e_{\mathrm{a}}-e_{\mathrm{s}}\right)+Q_{\mathrm{g}}+Q_{\mathrm{p}}+Q_{\mathrm{d}}+Q_{\mathrm{w}}
\end{aligned}
$$

where $K \downarrow$ is global solar radiation, direct beam plus diffuse $\left(\mathrm{W} / \mathrm{m}^{2}\right), \alpha$ is the surface albedo, $L^{*}$ is net long-wave radiation $\left(\mathrm{W} / \mathrm{m}^{2}\right), D_{\mathrm{h}}$ is the bulk-transfer coefficient for sensible heat $\left(\mathrm{MJ} / \mathrm{m}^{3} \mathrm{deg}\right), U_{\mathrm{z}}$ is the wind speed at a height $z$ $(\mathrm{m} / \mathrm{s}), T_{\mathrm{a}}$ and $T_{\mathrm{s}}$ are air and surface temperatures $\left({ }^{\circ} \mathrm{C}\right), D_{\mathrm{e}}$ is the bulk-transfer coefficient for latent heat $\left(\mathrm{MJ} / \mathrm{m}^{3} \mathrm{mbar}\right)$, and $e_{\mathrm{a}}$ and $e_{\mathrm{s}}$ are air and surface vapour pressures (mbar).

If it is assumed that the bulk-transfer coefficients for the melting ice are the same for both sensible and latent heat, they can be rendered dimensionally equivalent through use of the psychrometer constant $\gamma$ (mbar/deg). Equation (2) then becomes:

$$
\begin{aligned}
Q_{\mathrm{m}} & =K t(1-\alpha)+L^{*}+D_{\mathrm{h}} \cdot U_{\mathrm{z}}\left(T_{\mathrm{a}}-T_{\mathrm{s}}+\left(e_{\mathrm{a}}-e_{\mathrm{s}}\right) / \gamma\right)+ \\
& +Q_{\mathrm{g}}+Q_{\mathrm{p}}+Q_{\mathrm{d}}+Q_{\mathrm{w}} .
\end{aligned}
$$

Assuming that neither air bubbles nor a weathering crust exist (Müller and Keeler, 1969), $Q_{\mathrm{m}}$ can also be calculated from readings of surface ablation using Equation (4):

$$
Q_{\mathrm{m}}=d L M_{\mathrm{w}} /\left[\left(M_{\mathrm{w}} / \rho_{\mathrm{i}}\right)+\left(M_{\mathrm{s}} / \rho_{\mathrm{s}}\right)\right]
$$

where $d$ is the surface ablation rate $(\mathrm{m} / \mathrm{s}), L$ is the latent heat of fusion $\left(334 \times 10^{6} \mathrm{~J} / \mathrm{Mg}\right), \rho_{i}$ is the density of ice $\left(0.91 \mathrm{Mg} / \mathrm{m}^{3}\right), M_{\mathrm{s}}$ is the dried soil mass from a sample of the ice $(\mathrm{Mg}), \rho_{\mathrm{S}}$ is the specific gravity of the soil solids (assumed to be $2.65 \mathrm{Mg} / \mathrm{m}^{3}$ ), and $M_{\mathrm{w}}$ is the mass of the water from a sample of the ice $(\mathrm{Mg})$.

An error is introduced into Equation (4) by unfrozen moisture and as a result $Q_{\mathrm{m}}$ may be overestimated. However, since unfrozen moisture is only a small fraction of the total moisture content (frozen and unfrozen) of the face of a typical ground-ice slump, this error is minimal (Pufahl and Morgenstern, 1980). The transformation of $d$ into an energy flux then requires only the volumetric latent heat (represented by the terms to the right of $d$ in Equation (4)) which can be obtained through a measurement of the sediment content.

Data to calculate $Q^{*}$ for the ablating ice were collected at slump 1. Values were recorded at $10 \mathrm{~s}$ intervals and integrated over $30 \mathrm{~min}$ periods on two Campbell Scientific CR21 data loggers. The meteorological instruments used and their purposes are given in Table I. All instruments were mounted horizontally, except those located over the slump face. These were suspended parallel to the ablating ice and $1.5 \mathrm{~m}$ above it, on a frame which extended out from above the headwall (Fig. 4). The other sensors were mounted on undisturbed terrain 5-15 $\mathrm{m}$ back from the slump edge, with the exception of the thermohygrograph which was located in a Stevenson screen at the base camp.

Data to calculate $Q_{\mathrm{m}}$ were obtained by direct measurement of ice ablation using specially designed ablatometers (Fig. 5). Each ablatometer was mounted on dowels which had been inserted into holes in the ice. The holes were made using ice screws which also extruded a depthintegrated sample of the ice. This was collected for assessment of the excess ice content (see French, 1976, p. 76-77) in the field, and determination of the gravimetric moisture content in the laboratory. The spring-loaded slide on the ablatometer extends as the ice ablates, keeping the tip in contact with the ice face. This movement is transformed through rack-and-pinion gearing into rotation of a potentiometer spindle, and in turn into a change in

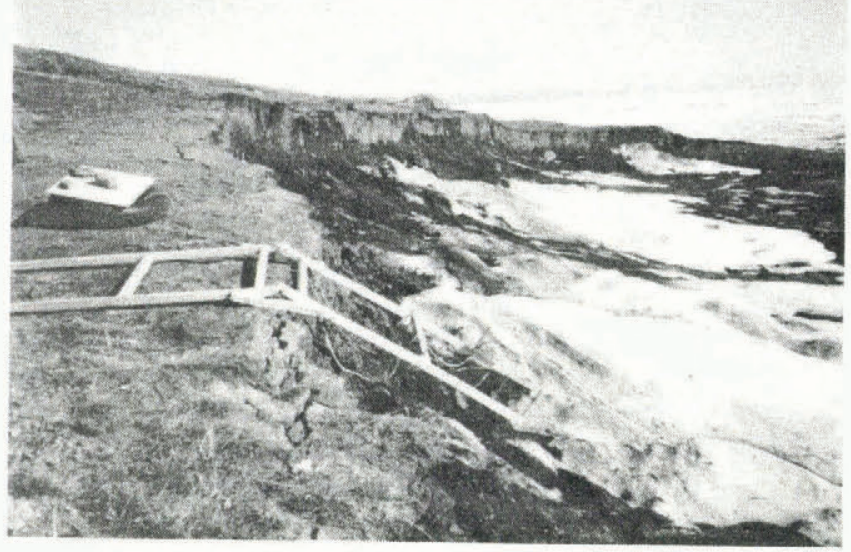

Fig. 4. Radiometer frame at slump 1, 30 May 1984. Note the snow banks present beneath the headwall which inhibit activity early in the spring. In the foreground is a typical tension crack which develops prior to headwall collapse. Inner tube was used to inflate net radiometer domes.

TABLE I. METEOROLOGICAL EQUIPMENT DEPLOYED IN 1984

Meteorological factor

Global radiation (horizontal)

Diffuse radiation (horizontal)

Global radiation (over slump face)

Net all-wave radiation (over slump face)

Net short-wave radiation (over slump face)

Air temperature $(1.5 \mathrm{~m} \mathrm{level})$

Wind speed $(2 \mathrm{~m}$ level)

Wind direction $(2 \mathrm{~m}$ level $)$

Precipitation

Relative humidity
Instrument

Pyranometer (Kipp and Zonen CM-10)

Pyranometer (Kipp and Zonen CM-6) with custom-made shadow band

Pyranometer (Kipp and Zonen CM-6)

Net radiometer (Swissteco S-1)

Net radiometer (Swissteco S-1)

Shielded thermistor (Campbell Scientific 101)

Cup anemometer (Met One, Inc.)

Wind vane (Met One, Inc.)

Tipping bucket rain-gauge

(Weathermeasure P501-I)

Thermohygrograph (Lambrecht) 


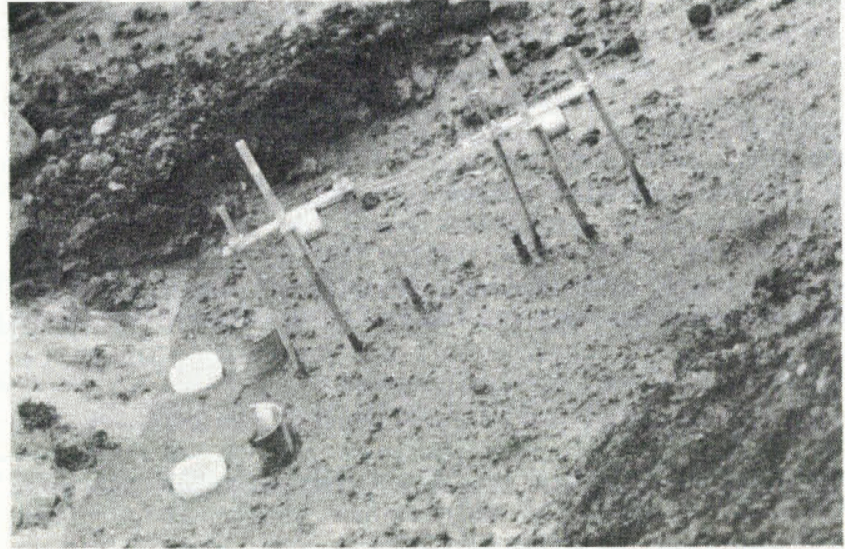

Fig. 5. Two ablatometers mounted on the ice face at slump I, 20 July 1984. Note supporting dowels frozen into the ice and the central slide which extends as the ice ablates. At bottom left are two small ice lysimeters used intermittently to evaluate latent-heat fluxes.

$\mathrm{mV}$ recorded by the datalogger. Programming of the CR21 gives an output to $\pm 0.1 \mathrm{~mm}$ of ablation. A full description of the instrument has been given elsewhere (Lewkowicz, 1985). The volumetric latent heat required for Equation (4) was derived from the two ice samples collected at each ablatometer location, either directly from a determination of gravimetric moisture content or, in a few cases when samples were not retained, from the excess ice content measured in the field and the best-fit line on Figure 6 .

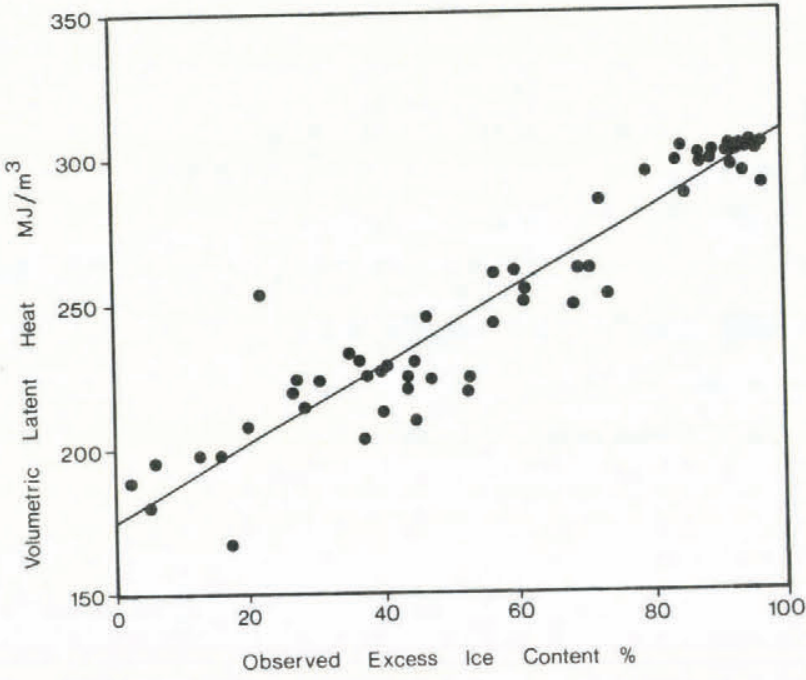

Fig. 6. Relationship between observed excess ice content and volumetric latent heat.

A large number of $30 \mathrm{~min}$ values of $Q_{\mathrm{m}}$ were obtained using the ablatometers. However, some problems existed in the measurements since occasionally the slides on the instruments failed to extend smoothly or stuck. A two-stage screening procedure was therefore developed to eliminate these data points from the records before analyses were undertaken. First, only time periods when at least two ablatometers were mounted on the ice face simultaneously were considered. Secondly, a calculation was undertaken for each ablatometer position involving subtraction of $Q^{*}$ from $Q_{m}$ to estimate the residual flux. While some differences were expected in the values of this residual due to variation in the vertical mounting position on the ice, an arbitrary decision was made that if differences were greater than $80 \mathrm{~W} / \mathrm{m}^{2}$ (representing approximately $1 \mathrm{~mm} / \mathrm{h}$ of ablation), then problems existed. For example, one or other of the ablatometers could have been moved slightly by headwall collapse, could be partially covered by collapsed material

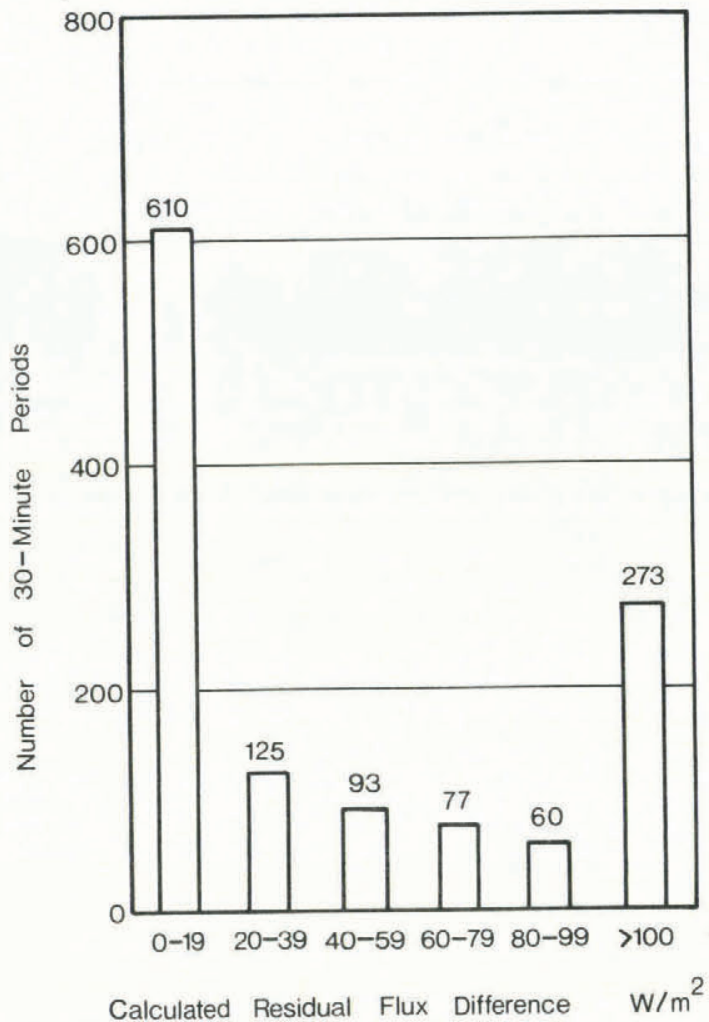

Fig. 7. Histogram of calculated differences of residual fluxes between ablatometers.

and therefore not exposed to full radiative exchange, could be located in a drainage rill on the ice face, or could be malfunctioning. This criterion acted as a filter and excluded approximately $25 \%$ of the records (Fig. 7).

$Q_{\mathrm{m}}$ calculated with Equation (4) from the ablatometer measurements can be substituted for the left-hand side of Equation (3). On the right-hand side of Equation (3), only the radiative components were fully monitored. No attempt was made directly to assess $Q_{\mathrm{h}}$, since it has been shown that due to advection well-developed temperature profiles do not exist above isolated ice faces (Pufahl, unpublished, p. 187-89). Some success was achieved in measuring $Q_{\mathrm{e}}$ using small ice lysimeters but the intermittent nature of the experiments precluded their use in the analyses presented in this paper.

The aim of the analysis of the radiation data was to estimate $Q^{*}$ for each particular ablatometer position. This was obtained by: (1) using a transformation based on Garnier and Ohmura (1968) and Fuggle (1970) to adjust the short-wave direct-beam radiation measured on the horizontal for the appropriate ice-face slope and aspect, including shadow effects as recorded in the field; (2) adding the slope diffuse-radiation component, with an assumption that only $65 \%$ of the horizontal flux reached the ablatometer position (obtained from the typical geometry of the slump headwall and the ablatometer position), and that the remaining $35 \%$ of the hemisphere was headwall or slump floor and contributed reflected short-wave diffuse radiation from these surfaces; (3) calculating the net short-wave flux using an albedo for the dirty ice of 0.15 (obtained from numerous measurements recorded from the frame over the face); and (4) adding the long-wave component obtained directly from the difference in signals between the net all-wave and net short-wave radiometers suspended over the face.

Some of the assumptions used in the transformation of the radiation data deserve additional comment. First, the estimate of the diffuse beam proportion reaching the ablatometers is based on an isotropic input but in practice the flux would have varied somewhat between mounting positions on the face. Secondly, some inaccuracy may have developed through the use of an average albedo, since it is believed that this varies rapidly both temporally and 
spatially in response to headwall collapse, and mud and water films flowing down the ice (Lewkowicz, 1985). Thirdly, the simple addition of the long-wave componen without transformation was employed, since measurements were only available from a specific location on the slump headwall which was not always the location of the ablatometers. Occasionally, long-wave response from the ice beneath the radiometer frame may have differed from that beneath the ablatometers because of variable coverage by collapsed material.

\section{RESULTS}

Following the stages of data transformation detailed above, it was possible to compare directly $Q_{\mathrm{m}}$ measured on the ice face at a particular slope and direction with $Q^{*}$ calculated for the same ice-face orientation. The results presented here examine this relationship over time under different synoptic conditions, and from a systematic viewpoint in order to develop a predictive equation for $Q_{\mathrm{m}}$

\section{Diurnal variation in $Q_{m}$ and $Q^{*}$}

Three sets of data are presented in Figure 8 to illustrate typical relationships between $Q_{\mathrm{m}}$ and $Q^{*}$ over $24 \mathrm{~h}$ periods. The values shown represent averages of $Q_{\mathrm{m}}$ recorded by two ablatometers and average $Q^{*}$ values for the two instrument positions.

Under conditions of high incident radiation, $Q_{\mathrm{m}}$ closely parallels $Q^{*}$ (Fig. 8a). For parts of the day, $Q_{m}$ is marginally greater than calculated $Q^{*}$, indicating ${ }_{\mathrm{small}}$ additional energy inputs to the ice from turbulent transfer and the other fluxes in Equation (3). At other times during the day the reverse is true, and it seems probable that some energy was being lost from the ice through the nonradiative terms. Part may have been lost to the atmosphere by $Q_{\mathrm{h}}$ and $Q_{\mathrm{e}}$, since Mackay (1978) has shown that under sunny conditions, films of water and mud on exposed ground ice can reach temperatures of $10^{\circ} \mathrm{C}$, while a muddy ice face with little water can attain a surface temperature of $17^{\circ} \mathrm{C}$. The maximum air temperature on 26 June was $11^{\circ} \mathrm{C}$, so that it is possible that the usually positive temperature and vapour-pressure gradients from the air to the ice were reversed for part of the day. In addition, some heat was likely removed from the ice surface by $Q_{\mathrm{g}}$. This flux is thought to be small, however, relating mainly to warming of the ice and soil mixture prior to thaw. Since the volumetric specific heats of both soil and ice are about $1.9 \mathrm{MJ} /\left(\mathrm{m}^{3} \mathrm{deg}\right.$ ) (Johnston and others, 1981) and the ground temperatures behind the face were probably in the range of $-5^{\circ}$ to $-10^{\circ} \mathrm{C}$, this heat loss represented on average less than $6 \%$ of the typical $300 \mathrm{MJ} / \mathrm{m}^{3}$ of latent heat required actually to thaw the ice. Finally, $Q_{m}$ values lower than calculated $Q^{*}$ values probably also relate to the activity of the slump headwall. Frequent minor collapse on 26 June provided irregular thin coverage of the face and likely reduced the amount of radiation actually reaching the ice. This explanation appears particularly probable for the period $17.30-20.00 \mathrm{~h}$ when $Q_{\mathrm{m}}$ fell below $Q^{*}$, then recovered (Fig. $8 \mathrm{a})$

During a partly cloudy day with high air temperatures (maximum of $17^{\circ} \mathrm{C}$ at $17.30 \mathrm{~h}$ ) the magnitude of $Q_{m}$ is very variable, responding to changes in energy inputs (Fig. $8 \mathrm{~b})$. There is a strong link between $Q^{*}$ and $Q_{\mathrm{m}}$ but the magnitude of the input fluxes other than $Q^{*}$ has increased compared to 26 June. Typical residual flux inputs are in the $200-300 \mathrm{~W} / \mathrm{m}^{2}$ range, with some still higher. Precipitation was recorded during $07.30-07.45 \mathrm{~h}$ and again during $15.00-15.30 \mathrm{~h}$ at intensities of $1 \mathrm{~mm} / \mathrm{h}$ and $1.5 \mathrm{~mm} / \mathrm{h}$, respectively. Theoretically, the energy flux due to rainfall $\left(Q_{\mathrm{p}}\right)$ depends on the specific heat of the water $(4.18 \mathrm{MJ} / \mathrm{Mg})$, the rainfall intensity, and the temperature difference between the precipitation and the ice face. Assuming that the ice was at $0^{\circ} \mathrm{C}$ and the raindrops reached the ambient air temperature, $Q_{\mathrm{p}}$ in the morning shower was $5 \mathrm{~W} / \mathrm{m}^{2}$, and in the afternoon it was $23 \mathrm{~W} / \mathrm{m}^{2}$. Given the magnitude of the other residual fluxes, the energy transferred by precipitation is relatively insignificant and no response to the rainfall can be observed in the ablation record (Fig. 8b). Since high-intensity storms are rare on Banks Island, rainfall probably affects ablation of exposed ground ice more by assisting in the clearance of the debris off the ice than in actually causing melt.

$Q_{\mathrm{m}}$ on an overcast cool day (maximum temperature of $4^{\circ} \mathrm{C}$ at $18.15 \mathrm{~h}$ ) is very low but consistently greater than $Q^{*}$ (Fig. 8c). While the magnitude of the fluxes is small, these data indicate that residual heat fluxes, probably mainly $Q_{\mathrm{h}}$ and $Q_{\mathrm{e}}$, may constitute over $50 \%$ of the energy supplied to the ice under such circumstances.

The data presented in Figure 8 show that the importance of $Q^{*}$ as a proportion of the energy causing ablation of the ice face in a ground-ice slump varies during a given day, and from one day to the next depending on synoptic conditions. Under sunny skies, $Q^{*}$ constitutes a high percentage of the energy input, while under cloudy conditions, both its absolute and relative importance are reduced. These results are similar to those obtained in the Arctic for the melt of the snow-pack (e.g. Heron and Woo, 1978; Woo, 1983) and for glacier ablation (e.g. Müller and Keeler, 1969; Braithwaite, 1981).

\section{Comparison of $Q^{*}$ and $Q_{m}$}

The overall relationship between $Q^{*}$ and $Q_{m}$ for all the data screened by the process described above is shown in Figure 9. There is a strong positive relationship with the majority of the points lying above the $1: 1$ line. This confirms that most of the time additional energy inputs are required for ablation and are supplied by the non-radiative fluxes in Equation (3). However, a significant number of
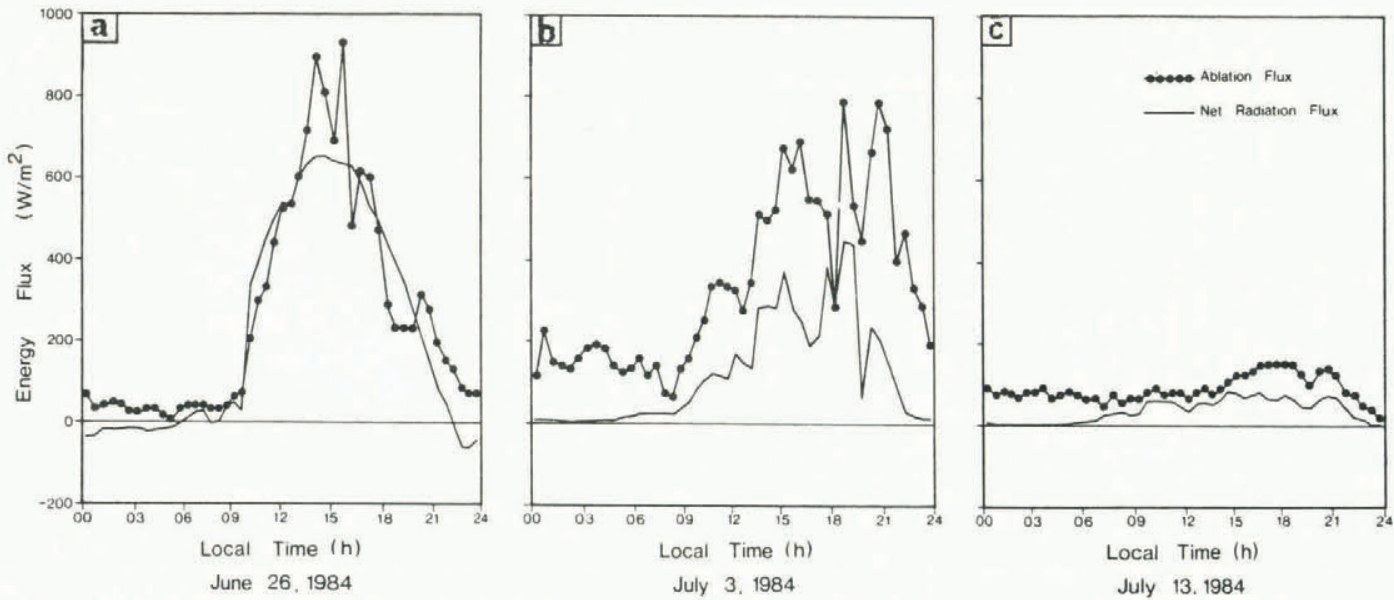

Fig. 8. Diurnal variation of net radiation and ablation fluxes. (a) Sunny conditions, 26 June 1984 (average of ice angles $20^{\circ}$ and $25^{\circ}$, ice facing $200^{\circ}$ ). (b) Cloudy, warm conditions, $3 \mathrm{July} 1984$ (ice angles $40^{\circ}$, ice facing $215^{\circ}$ ). (c) Overcast, cool conditions, 13 July 1984 (average of ice angles $25^{\circ}$ and $29^{\circ}$, ice facing $225^{\circ}$ ). 


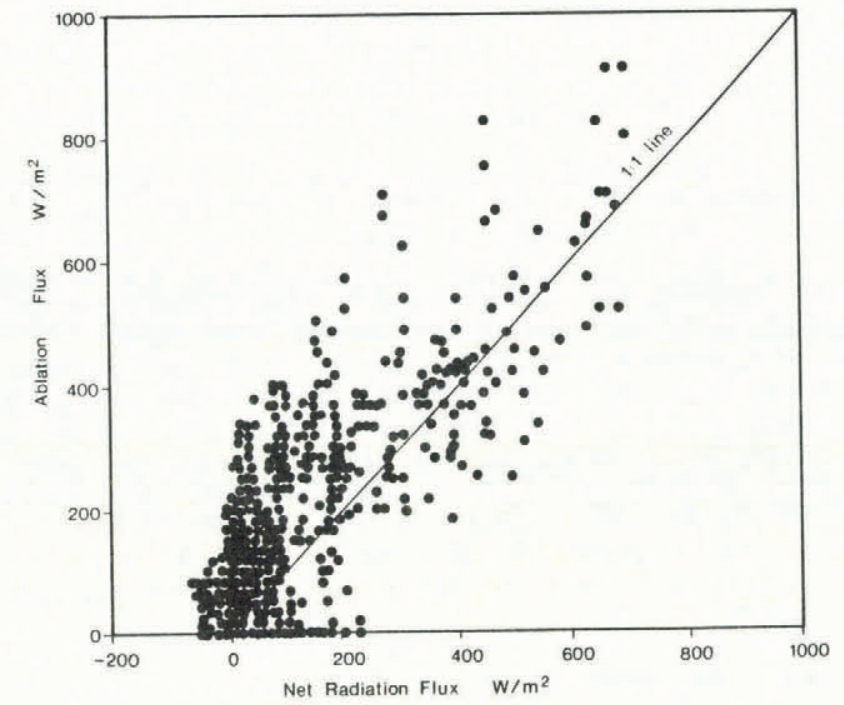

Fig. 9. Comparison of net radiation and ablation-flux values. Note: data screened to remove points when simultaneous residual flux values differ by $>80 \mathrm{~W} / \mathrm{m}^{2} ;$ two or three data points for each $30 \mathrm{~min}$ period depending on number of ablatometers mounted.

points fall below the $1: 1$ line, indicating either energy losses to the atmosphere and ground, and/or partial coverage of the ice face by debris preventing full absorption of the net radiation by the ice.

If the residuals away from the $1: 1$ line are plotted as a histogram (Fig. 10), the magnitude of the residual flux can be examined. $70 \%$ of the residuals are positive, and the modal group size represents an input flux to the ice of up to $49 \mathrm{~W} / \mathrm{m}^{2}$. $30 \%$ of the residuals are negative but the majority of these are within $50 \mathrm{~W} / \mathrm{m}^{2}$ of zero. These could represent small losses of heat to the atmosphere and ground, or errors in the assumptions used to calculate $Q^{*}$. Extreme negative residuals probably indicate coverage of the ice by debris which can effectively stop ablation (Lewkowicz, 1985). For example, several of these negative residuals are

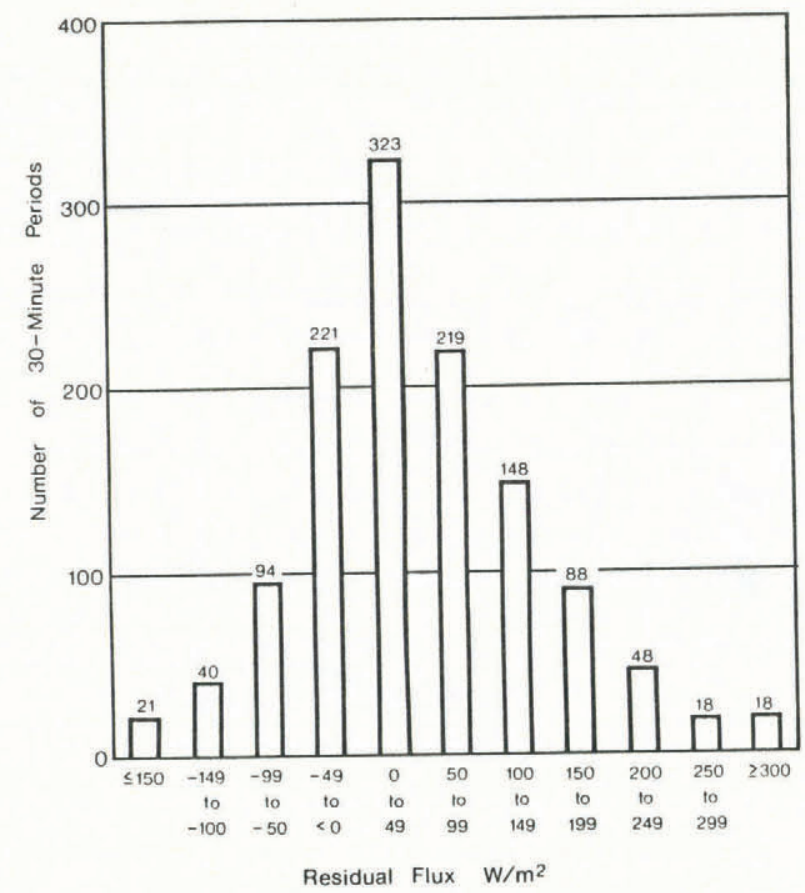

Fig. 10. Histogram of residual flux values. Note: data screened to remove points when simultaneous residual flux values differ by $>80 \mathrm{~W} / \mathrm{m}^{2}$; two or three data points for each $30 \mathrm{~min}$ period depending on number of ablatometers mounted. the points on Figure 9 with zero ablation and $Q^{*}$ values up to $200 \mathrm{~W} / \mathrm{m}^{2}$.

Regression of $Q_{m}$ versus meteorological factors

The data shown in Figure 9 indicate that prediction of $Q_{\mathrm{m}}$ using $Q^{*}$ alone will result in a fairly high standard error. In order to improve prediction, additional independent variables can be introduced into a multiple-regression equation. From Equation (3), the turbulent-energy term can be included if the wind speed $\left(U_{\mathrm{z}}\right)$, the air-to-ice temperature difference $\left(T_{\mathrm{a}}-T_{\mathrm{S}}\right)$ and the air-to-ice vapour-pressure difference $\left(e_{\mathrm{a}}-e_{\mathrm{S}}\right)$ are known. As an approximation, it can be assumed that $T_{\mathrm{S}}$ is $0^{\circ} \mathrm{C}$ and that $e_{\mathrm{S}}$ is the saturation vapour pressure at $0^{\circ} \mathrm{C}$. $T_{\mathrm{a}}$ and $U_{\mathrm{z}}$ were measured as detailed in Table I. To derive $e_{\mathrm{a}}$, the approximation in Dilley (1968) was used with inputs of the dry-bulb temperature recorded at the slump and relative humidity recorded by the thermohygrograph located at the base camp. Unlike the data shown in Figures 9 and 10, in order not to constrain the multiple regression unduly, each $30 \mathrm{~min}$ period for which screened data are available was represented only once in the sample $(n=534)$. The points were selected by alternating between the measurements when two ablatometers were mounted, and using one in three in turn when three ablatometers were in place.

The results of the multiple regression are given in Table II. The best-fit equation (No. 2) was obtained using $Q^{*}$ and the combined turbulent term as independent variables. This equation successfully explains $79 \%$ of the variation in $Q_{\mathrm{m}}$ and produces a standard error of $72 \mathrm{~W} / \mathrm{m}^{2}$. Cross-correlation between the independent variables is very low $(r=0.14)$. A graph of measured $Q_{\mathrm{m}}$ values versus those predicted by the best-fit equation (Fig. 11) shows a generally even distribution around the $1: 1$ line with a slight tendency for the equation to over-predict at low fluxes and under-predict at high values. The residuals in the multiple regression probably are mainly the result of varying conditions on the ice face that affect both the radiative- and turbulent-energy terms. Coverage of the ice by debris can cut off virtually all net radiation and atmospheric energy exchange to the ice. If the ice is exposed, however, mud and water films may be at significantly higher temperatures than those assumed (e.g. Mackay, 1978) so that surface temperatures and vapour pressures are variables rather than the constants used. Incorporating these factors into a predictive equation appears difficult since modelling of covered ablation, as described by Kraus (1973) for glacier surfaces, does not seem to be feasible due to the spatial and temporal variability of debris and water on the ice.

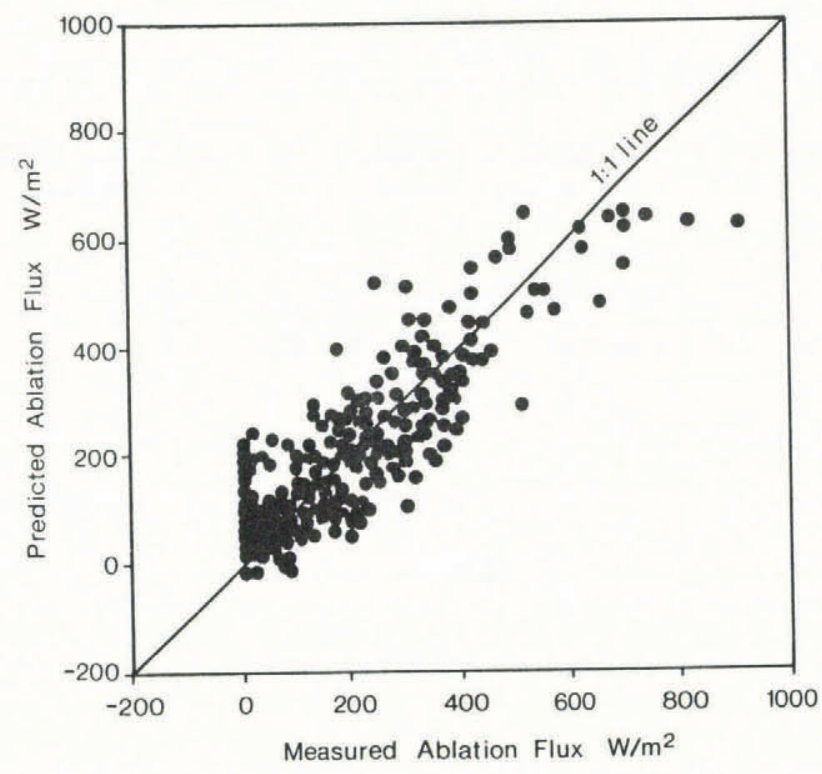

Fig. 11. Measured ablation flux versus predicted ablation flux, 1984 field season. Note: predicted values obtained from multiple-regression equation No. 2 (Table II); one data point for each 30 min period. 
TABLE II. REGRESSION COEFFICIENTS: ABLATION FLUX vs METEOROLOGICAL FACTORS

$\begin{array}{cccccccc}\begin{array}{c}\text { Equation } \\ \text { No. }\end{array} & r^{2} & \begin{array}{c}\text { Standard } \\ \text { error of } \\ \text { estimate }\end{array} & Q^{*} & T_{\mathrm{a}} & U_{\mathrm{z}} \cdot T_{\mathrm{a}} & U_{\mathrm{z}}\left(T_{\mathrm{a}}-T_{\mathrm{s}}+\left(e_{\mathrm{a}}-e_{\mathrm{s}}\right) / \gamma\right) & \text { Constant } \\ & & & & \mathrm{W} / \mathrm{m}^{2} & { }^{\circ} \mathrm{C} & \mathrm{m} \mathrm{deg} / \mathrm{s} & \mathrm{m} \mathrm{deg} / \mathrm{s} \\ 1 & 0.597 & 97.09 & 0.91 & \text { n.u. } & \text { n.u. } & \text { n.u. } & 66.44 \\ 2 & 0.793 & 69.60 & 0.83 & \text { n.u. } & \text { n.u } & 2.10 & 25.07 \\ 3 & 0.790 & 70.20 & 0.82 & \text { n.u. } & 3.25 & \text { n.u.. } & 20.30 \\ 4 & 0.393 & 119.21 & \text { n.u. } & 24.30 & \text { n.u. } & \text { n.u. } & 46.59\end{array}$

All coefficients are significant at better than the 0.001 level.

n.u. Not used.

Prediction of short-term ablation of ground ice is also possible using more limited meteorological information. The best single variable in predicting $Q_{\mathrm{m}}$ is $Q^{*}$, which explains almost $60 \%$ of the variance in the data (Table II, equation No. 1). In contrast, $T_{\mathrm{a}}$ as a predictor explains only $39 \%$ of the variation (Table II, equation No. 4). These results differ from those obtained by Kerfoot (unpublished) on Garry Island, N.W.T. (see location on Figure 2). Over periods ranging in length from 7 to $48 \mathrm{~h}$, amounts of ablation of ice faces were accurately predicted using the number of degree-hours $\left(n=22 ; \quad r^{2}=0.98\right) \quad$ (Kerfoot, unpublished, p. 169-70). The contrast between the results likely reflects (1) the longer time periods used at Garry Island, which would smooth the short-term variability in the $30 \mathrm{~min}$ records (e.g. Fig. 8a), and (2) the orientation of slump 1 towards the south-west so that it is exposed to high $Q^{*}$ inputs, while the Garry Island slump faces north-east and is probably more affected by $Q_{\mathrm{h}}$ and $Q_{\mathrm{e}}$, themselves strongly linked to air temperature.

It is interesting to note that the correlation of $Q_{\mathrm{m}}$ and $Q^{*}$ at slump 1 is far higher than that obtained from studies of glaciers in the High Arctic. At White Glacier on Axel Heiberg Island, and Sverdrup Glacier on Devon Island, for example, $r$ values for correlation between measured $Q_{\mathrm{m}}$ and $Q^{*}$ ranged from -0.22 to +0.27 and none was significant (Braithwaite, 1981). The difference in results is probably linked to the development of weathering crusts on the ice. Such crusts can cause significant underestimates of $Q_{\mathrm{m}}$ during their growth and overestimates during their decay. While important on glaciers, weathering crusts were not observed to develop on the exposed ground ice at slump 1 .

Test of the regression

A data set collected in 1983 at slump 1 can be used to test the predictive value of the multiple regression. In 1983, ablation rates were determined by measuring the emergence of white flexible plastic tubes $(4 \mathrm{~mm}$ diameter) from holes drilled into the ice face. On 12 August, 35 of these tubes were inserted into the ice face around the slump and their re-emergence monitored at intervals of between 2 and $10 \mathrm{~h}$. Not all tubes were measured on each occasion, since some were covered by debris from headwall collapse. The total number of measurements made over a $30 \mathrm{~h}$ period was $144 . Q^{*}$ and $Q_{\mathrm{m}}$ were calculated for each tube location in the same way as for the 1984 data. Relative humidity was not recorded at the site in 1983, so the predictive equation used involves only $Q^{*}$ and a combination of $U_{\mathrm{z}}$ and $T_{\mathrm{a}}$ (Table II, equation No. 3 ).

The comparison of measured and predicted $Q_{m}$ for 12-13 August 1983 is shown in Figure 12. The distribution of data points around the $1: 1$ line appears reasonable up to observed flux values of $600 \mathrm{~W} / \mathrm{m}^{2}$, but above this level the equation apparently under-predicts. However, it is quite likely that the performance of the regression equation is superior to that indicated by the scatter and that in this case it is the measured $Q_{\mathrm{m}}$ values that are too high. This hypothesis is based on observations of radiation pitting around the plastic tubes which may have inflated $Q_{m}$ values. Some evidence for this is that the maximum $Q_{m}$ value recorded over any $2 \mathrm{~h}$ period with the ablatometers in

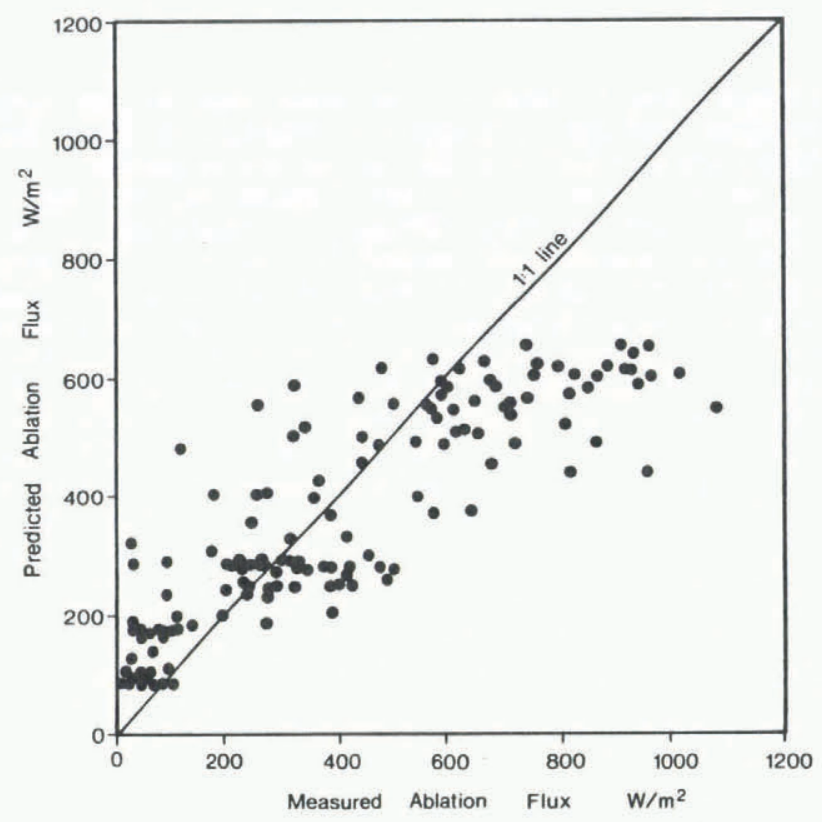

Fig. 12. Measured ablation flux versus predicted ablation flux, 12-13 August 1983. Note: measured fluxes are averages of ablation over periods ranging between 2 and $10 \mathrm{~h}$; predicted values obtained for $30 \mathrm{~min}$ periods from multiple-regression equation No. 3 (Table II) then averaged over field-measurement period.

1984 was $760 \mathrm{~W} / \mathrm{m}^{2}$, while a considerable number of the measured values shown in Figure 12 exceed $800 \mathrm{~W} / \mathrm{m}^{2}$. It appears likely, therefore, that the regression equation actually performed better than indicated by the displacement of points away from the 1:1 line shown in Figure 12.

\section{Comparison with other studies}

Data collected at slump 1 can be compared with results obtained in studies from Mayo, Yukon Territory (Burn, unpublished), Garry Island, N.W.T. (Kerfoot, unpublished), and Fort Simpson, N.W.T. (Pufahl and Morgenstern, 1980). It is not possible to compare the ablation rates with more commonly measured headwall-retreat rates (e.g. Lamothe and St-Onge, 1961; Mackay, 1966; French and Egginton, 1973; McRoberts and Morgenstern, 1974; Heginbottom, 1984) since links between them are affected by slump headwall geometry and time lags.

The maximum $30 \mathrm{~min} Q_{\mathrm{m}}$ value measured at slump 1 was $910 \mathrm{~W} / \mathrm{m}^{2}$ which corresponded to an ablation rate of $10.8 \mathrm{~mm} / \mathrm{h}$. Maximum ablation rates for $3 \mathrm{~h}$ and $24 \mathrm{~h}$ periods, for which comparable data are available, are somewhat lower (Table III). At Fort Simpson, an average ablation rate of $140 \mathrm{~mm} / \mathrm{d}$ was obtained for the period between 21 June and 21 July (Pufahl and Morgenstern, 1980). However, this figure was for horizontal retreat of the ice and would be reduced to about $100 \mathrm{~mm} / \mathrm{d}$ of ablation measured orthogonally to the $45^{\circ}$ face. Overall, maximum 
TABLE III. ABLATION RATES OF EXPOSED GROUND ICE

Source

Location

\section{Maximum $3 \mathrm{~h}$ ablation Maximum $24 \mathrm{~h}$ ablation}

\begin{tabular}{ccccccc}
$\begin{array}{c}\text { Amount } \\
\text { mm }\end{array}$ & Date & $\begin{array}{c}\text { Amount } \\
\text { mm }\end{array}$ & \multicolumn{2}{c}{ Date } \\
27 & 25 & June 1984 & 100 & $3-4$ & July 1984 \\
n.a. & n.a. & $150^{*}$ & $8-9$ July 1965 \\
$60^{\dagger}$ & 27 July 1982 & $155^{\ddagger}$ & $8-9$ July 1982
\end{tabular}

* p. 166 , fig. 23.

p. 67 , fig. 4.3 .

‡ p. 62 , fig. 4.1 . ablation rates at slump 1 are lower than at the other locations, and this is probably a reflection of lower turbulent-energy transfers at the more northerly location.

A comparison of the energy-balance data recorded at slump 1 and at Fort Simpson is complicated by the geometric transformation required for ablation in the latter data set. The contribution made by $Q^{*}$ to $Q_{\mathrm{m}}$ at Fort Simpson was estimated to have been $43 \%$ over a 4 week period (Pufahl and Morgenstern, 1980). If the transformation due to the slope of the ice is applied to these data, this figure rises to approximately $62 \%$. At slump 1, a figure of $60 \%$ was obtained from the data used in the multipleregression equation. This may be a conservative estimate of the importance of $Q^{*}$, however, since continuous records of $Q_{\mathrm{m}}$ were more often obtained during periods of low energy inputs when headwall activity was reduced and the ablatometers were less likely to be hit by collapse. Consequently, the $60 \%$ value is derived from a frequency distribution that is somewhat biased towards periods with low $Q^{*}$ values. As shown above, this in turn will favour periods when $Q^{*}$ is proportionally less important as a cause of ablation.

The bias in the data from slump 1 is unlikely to raise the importance of $Q^{*}$ to more than $65-70 \%$ of the energy causing ablation. Thus, the Banks Island and adjusted Fort Simpson resuits are quite similar in spite of the $10^{\circ}$ latitudinal difference between the sites and the $180^{\circ}$ difference in aspect of the ice faces. Additional studies are needed to separate out the importance of aspect, latitude, and synoptic conditions during the measurement period before it can be determined whether this similarity is more than coincidence.

\section{CONCLUSIONS}

Two major conclusions can be drawn from this study.

First, the single factor that best explains the variation in the ablation of an exposed ground-ice face on south-west Banks Island is net radiation. However, the importance of net radiation as an energy input is variable and dependent on synoptic conditions. Under sunny skies, net radiation provides almost all the energy needed for ablation, but during overcast periods it may supply less than half of the ablation flux. Over the term of the study in June and July 1984 , at least $60 \%$ of the energy used for ablation was supplied by net radiation.

Secondly, most short-term variation in ablation can be explained using a multiple-regression equation with independent variables of net radiation and a turbulentenergy term. This equation gave an $r^{2}$ value of 0.79 , and much of the residual variance in the dependent variable probably resulted from variations in the boundary conditions of the ice face as a consequence of headwall collapse. The degree of fit and the absence of strong trends in the residuals from the equation indicate that it is possible to predict short-term ablation rates of exposed ground ice from meteorological information.

\section{ACKNOWLEDGEMENTS}

This study was supported by funds from the Natural Sciences and Engineering Research Council of Canada (operating grant A2643 and northern supplement N0082), and a University of Toronto grant. Generous logistical support was provided through G.D. Hobson, Director, Polar Continental Shelf Project, Department of Energy, Mines and Resources, Canada, and by the staff of the Inuvik Scientific Research Laboratory.

The author is grateful for the excellent field assistance of P.C. Graham, J.M.C. Lalonde, A. Pilipaitis, C.A Roncato, and A. Rothschild. This work could not have been undertaken without their help. Helpful comments on an earlier version of the manuscript were kindly provided by H.M. French, J.M.C. Lalonde, D.S. Munro, and two anonymous reviewers. The figures were drafted in part by P.C. Graham.

\section{REFERENCES}

Braithwaite, R.J. 1981. On glacier energy balance, ablation, and air temperature. Journal of Glaciology, Vol. 27, No. 97 , p. 381-91.

Brown, J., and Kreig, R.A., eds. 1983. Guidebook to permafrost and related features along the Elliott and Dalton highways, Fox to Prudhoe Bay, Alaska. Fairbanks, AK, Alaska Division of Geological and Geophysical Surveys. (Guidebook No. 4, Fourth International Conference on Permafrost, Fairbanks, Alaska.)

Burn, C.R. Unpublished. Investigations of thermokarst development and climatic change in the Yukon Territory. [M.A. thesis, Carleton University, Ottawa, 1982.]

Dilley, A.C. 1968. On the computer calculations of vapour pressure and specific humidity gradients. Journal of Applied Meteorology, Vol. 7, p. 717-19.

French, H.M. 1976. The periglacial environment. London, Longmans.

French, H.M., and Egginton, P. 1973. Thermokarst development, Banks Island, western Canadian Arctic. Permafrost. Second International Conference, 13-28 July 1973, Yakutsk, U.S.S.R. North American Contribution. Washington, DC, National Academy of Sciences, p. 203-12.

Fuggle, R.F. 1970. A computer programme for determining direct short-wave radiation income on slopes. Climatological Bulletin, Vol. 7, p. 8-16.

Garnier, B.J., and Ohmura, A. 1968. A method of calculating the direct shortwave radiation income of slopes. Journal of Applied Meteorology, Vol. 7, p. 796-800.

Harry, D.G. Unpublished. Aspects of the permafrost geomorphology of southwest Banks Island, western Canadian Arctic. [Ph.D. thesis, University of Ottawa, Ottawa, 1982.] 
Harry, D.G., and others. 1983. Coastal conditions and processes, Sachs Harbour, Banks Island, western Canadian Arctic, by D.G. Harry, H.M. French, and M.J. Clark. Zeitschrift für Geomorphologie, Supplementband 47, p. 1-26.

Heginbottom, J.A. 1978. An active retrogressive thaw flow slide on eastern Melville Island, District of Franklin. Geological Survey of Canada. Paper 78-1A, p. 525-26.

Heginbottom, J.A. 1984. Continued headwall retreat of a retrogressive thaw flow slide, eastern Melville Island, Northwest Territories. Geological Survey of Canada. Paper 84-1B, p. 363-65.

Heron, R., and Woo, M.-k. 1978. Snowmelt computations for a high Arctic site. Proceedings of the Eastern Snow Conference, 35th annual meeting, p. 162-72.

Hughes, O.L. 1972. Surficial geology and land classification, Mackenzie Valley transportation corridor. Canadian Northern Pipeline Research Conference, Ottawa, February 1972. Proceedings. Ottawa, National Research Council of Canada. Associate Committee on Geotechnical Research, p. 17-24. (Technical Memorandum 104.)

Johnston, G.H., and others. 1981. Engineering characteristics of frozen and thawing soils, by G.H. Johnston, B. Ladanyi, N.R. Morgenstern, and E. Penner. (In Johnston, G.H., ed. Permafrost: engineering design and construction. Toronto, etc., John Wiley and Sons, p. 73-147.)

Kerfoot, D.E. Unpublished. The geomorphology and permafrost conditions of Garry Island, N.W.T. [Ph.D. thesis, University of British Columbia, Vancouver, 1969.]

Kraus, H. 1973. Energy exchange at air-ice interface. The role of snow and ice in hydrology. Proceedings of the Banff Symposia, September 1972, Paris, UnescoWMO-IAHS, Vol. 1, p. 128-64.

Lamothe, C., and St-Onge, D. 1961. A note on a periglacial erosional process in the Isachsen area, N.W.T. Geographical Bulletin, No. 16, p. 104-13.

Lewkowicz, A.G. 1985. Use of an ablatometer to measure short-term ablation of exposed ground ice. Canadian Journal of Earth Sciences, Vol. 22, No. 12, p. 1767-73.

Mackay, J.R. 1966. Segregated epigenetic ice and slumps in permafrost, Mackenzie Delta area, N.W.T. Geographical Bulletin, Vol. 8, p. 59-80.

Mackay, J.R. 1978. The surface temperature of an ice-rich melting permafrost exposure, Garry Island, Northwest Territories. Geological Survey of Canada. Paper 78-1A, p. 521-22.
McRoberts, E.C., and Morgenstern, N.R. 1974. The stability of thawing slopes. Canadian Geotechnical Journal, Vol. 11, No. 4, p. 447-69.

Male, D.H., and Gray, D.M. 1981. Snowcover ablation and runoff. (In Gray, D.M., and Male, D.H., eds. Handbook of snow: principles, processes, management and use. Toronto, etc., Pergamon Press, p. 360-436.)

Müller, F., and Keeler, C.M. 1969. Errors in short-term ablation measurements on melting ice surfaces. Journal of Glaciology, Vol. 8, No. 52, p. 91-105.

Phillips, D.W., and Aston, D. 1980. Canadian solar radiation data. Downsview, Ontario, Environment Canada. (CLI 2-80.)

Pufahl, D.E. Unpublished. The behaviour of thawing slopes in permafrost. [Ph.D. thesis, University of Alberta, Edmonton, 1976.]

Pufahl, D.E., and Morgenstern, N.R. 1980. The energetics of an ablating headscarp in permafrost. Canadian Geotechnical Journal, Vol. 17, No. 4, p. 487-97.

Pufahl, D.E., and others. 1974. Observations on recent highway cuts in permafrost, by D.E. Pufahl, N.R. Morgenstern, and W.D. Roggensack. Ottawa, Information Canada. (Task Force on Northern Oil Development. Environmental-Social Committee, Northern Pipelines. Report No. 74-32.)

Rothschild, A. Unpublished. Ground ice petrography, Sand Hills moraine, southwest Banks Island, N.W.T. [M.A. thesis, University of Ottawa, Ottawa, 1985.]

Shu Daode, and Huang Xiaoming. 1983. Design and construction of cutting at sections of thick-layer ground ice. Permafrost. Fourth International Conference, July 17-22, 1983 [Fairbanks, Alaska]. Proceedings. Washington, DC, National Academy Press, p. 1152-56.

Smith, N., and Berg, R. 1973. Encountering massive ground ice during road construction in central Alaska. Permafrost. Second International Conference, 13-28 July 1973, Yakutsk, U.S.S.R. North American Contribution. Washington, DC, National Academy of Sciences, p. 730-36.

Vincent, J.-S. 1982. The Quaternary history of Banks Island, N.W.T., Canada. Géographie Physique et Quaternaire, Vol. 36, Nos. 1-2, p. 209-32.

Vincent, J.-S. 1983. La géologie du Quaternaire et la géomorphologie de l'île Banks, Arctique canadien. Geological Survey of Canada. Memoir No. 405.

Woo, M.-K. 1983. Hydrology of a drainage' basin in the Canadian high Arctic. Annals of the Association of American Geographers, Vol. 73, p. 577-96. 